\title{
Gender differences in the learning and teaching of surgery: a literature review
}

\author{
Carmen Mesas Burgos', Anna Josephson² \\ ${ }^{1}$ Division of Pediatric Surgery, Department of Women's and Children's Health, Karolinska Institutet, Sweden \\ ${ }^{2}$ Department of Neuroscience, Karolinska Institutet, Sweden \\ Correspondence: Carmen Mesas Burgos, Division of Pediatric Surgery, Department of Women’s and Children's Health, \\ Karolinska University Hospital, Q3:03, SE-17176 Stockholm, Sweden. Email: Carmen.Mesas.Burgos@ki.se
}

Accepted: May 24, 2014

\begin{abstract}
Objectives: To explore evidence concerning gender differences in teaching and learning in surgery to guide future initiatives.

Methods: This systematic review was conducted searching in the following electronic databases: MEDLINE, EMBASE, CINAHL, PsycINFO, ERIC, Web of Science, Scopus and PubMed. All studies related to gender differences in surgical education, teaching or learning of surgery at an undergraduate level were included. Data was extracted and critically appraised. Gender differences in learning, teaching, skills acquisition, perceptions and attitudes, interest on surgery, personality and factors influencing interest in surgical careers were differentiated.
\end{abstract}

Results: There is an underrepresentation of women in surgical academia, due to lack of role models and gender awareness. It is not clear whether or not gender itself is a factor that affects the learning of surgical tasks. Female students pursuing a surgical career had experienced sexual harassment and gender discrimination that can have an effect on the professional identity formation and specialty choice. There are differences in personality among female and male students interested in surgery. Gender is a determining factor to choose surgery, with a consistent lower proportion of women compared interested in pursuing a surgical career. Mentoring and personality fit are important in medical student's specialty selection. Female students are more likely to be discouraged from pursuing a surgical career by a lack of female role models.

Conclusions: Bias against women in surgery still exists. There is a lack of studies that investigate the role of women in the teaching of surgery.

Keywords: Gender, surgery, medical education, surgical education, undergraduate, teaching and learning

\section{Introduction}

A considerable demographic shift has occurred and continues to occur in medicine as older physicians retire and a greater proportion of women enter the profession. The number of women entering medical schools today exceeds $50 \%$, and the number in hospital specialties is expected to exceed $50 \%$ by $2016 .{ }^{1,2}$ As the gender ratio in the profession changes, the term "feminization of medicine", referring to the medical profession becoming less dominated by men, has been a topic of debate in the medical literature. ${ }^{3}$ Women are increasingly entering the surgical profession, ${ }^{4}$ although the specialty is still male-dominated, with women representing $10-20 \%$ of the surgical workforce according to different studies. ${ }^{2,5}$ Also, the percentage of women as medical school faculty members holding associate or full professor rank remains well below the percentage of men. ${ }^{6}$ There is a global concern regarding the trend towards decreased interest in surgical careers: family considerations, increased stress and long work hours, sacrifice of personal time, and lack of (or negative) role models are the most common negative factors. ${ }^{7}$ In this context, very little is known of genderrelated differences among medical educators in surgery at an undergraduate level. The apparent disparity in numbers and gender ratio relationship could possibly have some impact in students' interest in pursuing a surgical career.

\section{Objectives}

The overall objective with this review was to further the understanding regarding gender equality in surgical education to guide future initiatives. We aimed to explore the literature to ascertain whether there are gender differences in the teaching and learning of surgery, and if there are any gender differences when choosing and progressing in a 
career in surgery, and to explore the possible explanations to gender disparities within surgical education.

\section{Methods}

\section{Focused questions}

We aimed to explore evidence concerning gender differences in teaching and learning in surgery at an undergraduate level by answering the following questions:

1. Does gender influence the teaching of surgery? Is there any gender that is predominantly involved in teaching surgery for undergraduate medical students?

2. Does gender influence the learning process of surgery?

3. Is there any gender that predominantly is interested in surgical specialties?

4. If there are differences, how can they be explained?

5. We focused on studies that investigated gender differences in the teaching and learning of surgery in medical education. We applied the PICO terminology as described by Cook and West. ${ }^{8}$

\section{Search strategy}

The search for relevant literature was performed in March 2013 by two investigators (CMB and AJ), who independently searched the following electronic databases: MEDLINE, EMBASE, CINAHL, PsycINFO, ERIC, Web of Science, Scopus and PubMed.

The key search terms used included: gender, medical education, surgical education, surgery, undergraduate, academia, teaching and learning; and the following $\mathrm{MeSH}$ terms: education, medical, surgery, undergraduate, faculty, teaching, female, male, sex distribution, students.

\section{Inclusion and exclusion criteria}

All studies related to gender differences in surgical education, teaching or learning of surgery, at an undergraduate level were included in the first stage. All articles not relevant for our purpose (gender differences in outcomes after surgical procedures, gender differences among professionals in surgical specialties) were excluded after reading the title (Step 1). After removal of duplicate records, all the titles and abstract were screened, and the final selection of articles was based on the following criteria (Step 2):

1. Published after 1990, and

2. Studies that focused on gender differences in academic surgery, or

3. Studies that focused on gender differences in the teaching of surgery at an undergraduate level, or

4. Studies that focused on gender differences in the learning of surgery at an undergraduate level, or

5. Studies that focused on gender differences in interest on surgical specialties

\section{Data abstraction/extraction}

A standardized data extraction and critical appraisal instrument was constructed by the investigators using an electronic spreadsheet (Microsoft Office for Macintosh 2011) for the purpose of this review.

\section{Analysis}

Discrepancies in opinions between the investigators were identified and final consensus was reached through discussion. The study methodologies were analyzed, and common themes from study findings were defined. Gender differences in learning were differentiated from gender differences in teaching. Gender differences in learning were differentiated in skills acquisition and perceptions and attitudes. Gender differences in interest on surgery were differentiated in factors influencing interest in surgical careers and personalities.

\section{Results}

\section{Trial flow}

The literature search produced a total of 547 articles in the Web of Science, 705 in Scopus, 1,465 in PubMed, 127 in ERIC, 29 in Medline, 150 in EMBASE, 13 in PsycInfo and 58 in CINAHL, with a total 1,650 non-duplicated titles. After screening all titles, many were excluded for not being relevant for our purpose.

After screening all titles and abstracts for potentially relevant articles, a total of 173 non-duplicated articles were obtained in full text for closer inspection, and of these 77 met the selection criteria (Figure 1).

\section{Study characteristics}

The selected studies were classified in four categories:

\section{Gender differences in academic surgery}

There is a gross underrepresentation of women in the leadership positions of surgical departments. Both Flannery and Zhuge discuss the perception of a "glass ceiling", a metaphor for the observation that how, despite the increasing numbers of female medical students, and increasing number of women entering surgical specialties, fields traditionally held by men, their advancement into the most prestigious, highest-paying, and leadership positions is still limited. ${ }^{9,10}$ Women in academic surgery seem to be less likely to be promoted than their comparably credentialed male colleagues. ${ }^{10,11}$ Despite the year of publication, the same pattern seems to persist according to a recently published survey, where the female participants, senior surgical residents and early career faculty members, experienced gender as a limitation to access a career in academic surgery. ${ }^{6}$ 


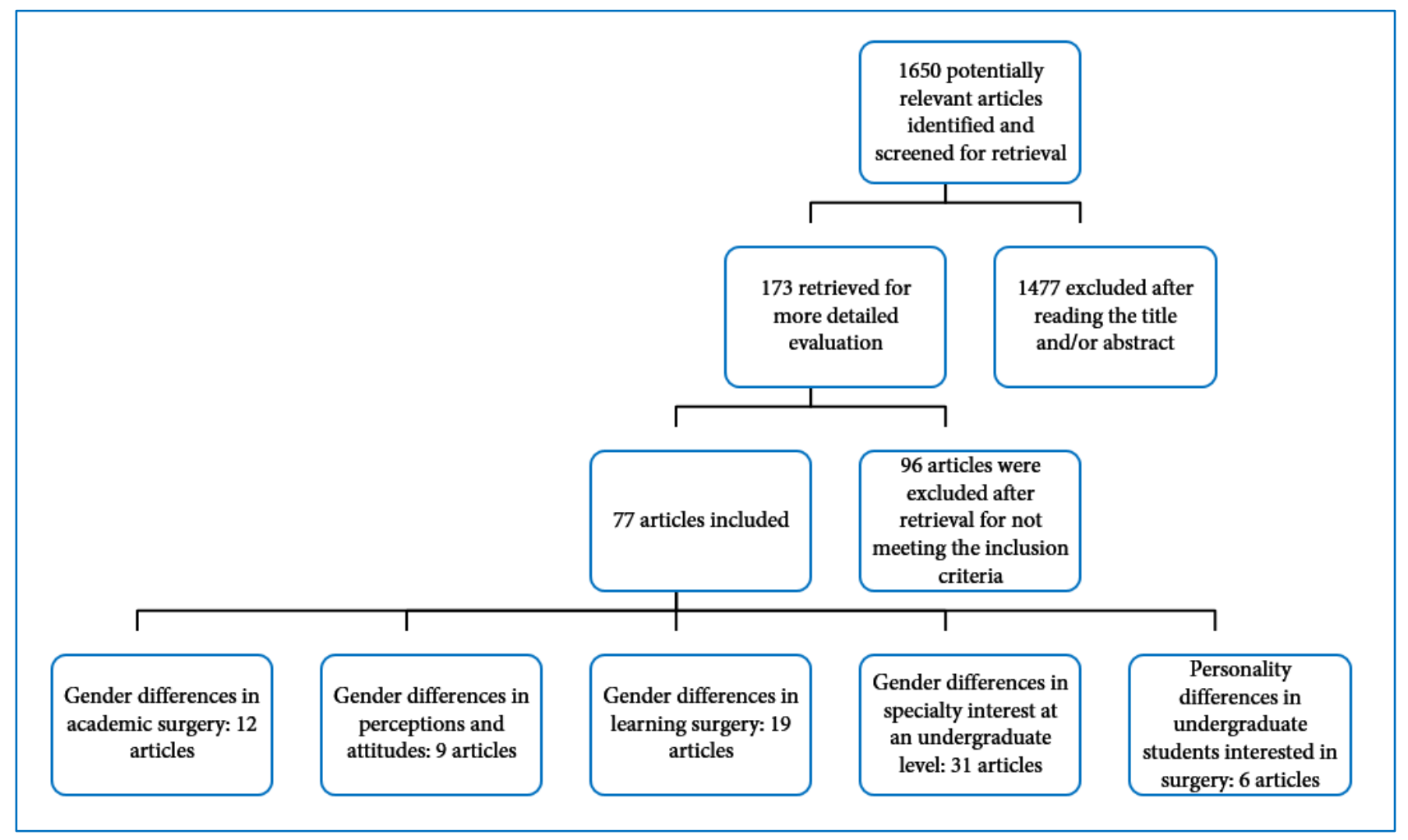

Figure 1. Trial flow

Similar results were reported by Sexton and colleagues when they examined the trends in gender-based advancement in academic surgery by performing a comparative analysis of the rate of change in the percentage of medical students, surgery residents, and full professors of surgery who are women, and concluded that percentage of full professors in surgery who are women is increasing at a rate disproportionately slower than the increases in female medical students and surgery residents. ${ }^{12}$

Jonasson reviewed the number of women in the major surgical societies and organizations in US, and found that women are underrepresented, also in the leading positions of academic departments of surgery. ${ }^{13}$ Neither does the representation of women in professional societies and editorial boards reflect their presence in medical specialties, with an overrepresentation of men holding these positions $(83 \%){ }^{14}$

Despite being in minority, women are more likely to engage in clinical teaching. Klingensmith and Anderson performed a cross-sectional survey of membership of the Association for Surgical Education, and although the precise numbers of women in the US who are involved in educational scholarship is unknown, the numbers appear to be substantial; the percentage of women who have participated in the American College of Surgeons' 'Surgeons as Educators" course over the past 11 years of the course's existence is $20.4 \%$, and the number of women who have participated in the Association for Surgical Education's "Surgical Education Research Fellowship" is 32\% over the 10 years of its existence. These data suggest that women seek advanced training in educational scholarship in greater proportions than do men, given the proportions of female to male surgeons at large. ${ }^{15}$ Mendoza and colleagues also reported a majority of female educators, $58 \%$, with doctoral degree and full-time faculty appointment in a surgery department in an American or Canadian institution. ${ }^{16}$ Although the number of participants in this study is low (only 12 respondents), the results are in accordance with those from the survey performed by Tesch and colleagues, where women are more likely to engage in clinical teaching ( $16.7 \%$ of female vs. $14.8 \%$ of male surgeons). ${ }^{11}$

There are no significant differences between male and female junior surgeons involved in teaching undergraduates. They have similar attitudes toward, and practices in, voluntary undergraduate teaching. ${ }^{17}$ Prichard and colleagues performed a survey in an attempt to clarify whether there are differences between the attitudes and practices of male and female junior doctors regarding the practice of undergraduate teaching in the UK. With a majority of male doctors in surgical specialties $(68.1 \%)$, there were no significant differences between the genders regarding the self-reported quantity of teaching provided to undergraduates. There are, however, differences in attitudes and personalities. Male doctors perceived themselves as more confident educators when compared to female doctors, but this could reflect cohort demographics in which a greater proportion of male doctors were more senior ${ }^{17}$ (Table 1). 
Table 1. Gender differences in academic surgery

\begin{tabular}{|c|c|c|c|c|c|}
\hline Author & Year & Participants & Type of study & Study objective & Findings \\
\hline Cochran & 2013 & $\begin{array}{l}\text { Senior surgical residents } \\
\text { and early career surgical } \\
\text { faculty members }\end{array}$ & Survey & $\begin{array}{l}\text { To test the hypothesis than } \\
\text { female surgeons perceive } \\
\text { different barriers to } \\
\text { academic careers relative to } \\
\text { their male colleagues }\end{array}$ & $\begin{array}{l}\text { Women experience gender as a barrier to develop a } \\
\text { career in academic surgery. }\end{array}$ \\
\hline Sexton & 2012 & $\begin{array}{l}\text { Member of American } \\
\text { Association of Medical } \\
\text { Colleges }\end{array}$ & Cohort study & $\begin{array}{l}\text { To examined the trends for } \\
\text { gender-based advancement } \\
\text { in academic surgery }\end{array}$ & $\begin{array}{l}\text { The percentage of full professors in surgery who are } \\
\text { women is increasing at a rate disproportionately } \\
\text { slower than the increase in female medical students } \\
\text { and surgery residents. }\end{array}$ \\
\hline Prichard & 2011 & $\begin{array}{l}\text { Non-consultant hospital } \\
\text { doctors }\end{array}$ & Survey & $\begin{array}{l}\text { To investigate differences in } \\
\text { attitudes and practices of } \\
\text { male and female junior } \\
\text { doctors in the practice of } \\
\text { undergraduate teaching. }\end{array}$ & $\begin{array}{l}\text { No significant differences between the genders } \\
\text { regarding the self-reported quantity of teaching } \\
\text { provided to undergraduates. Male and female doctors } \\
\text { have similar attitudes toward, and practices in, } \\
\text { voluntary undergraduate teaching. }\end{array}$ \\
\hline Zhuge & 2011 & & Review & $\begin{array}{l}\text { To analyze the factors that } \\
\text { contribute to the glass } \\
\text { ceiling phenomenon }\end{array}$ & $\begin{array}{l}\text { Traditional gender roles, manifestations of sexism in } \\
\text { the medical environment, and lack of effective } \\
\text { mentors make women advance more slowly than men } \\
\text { in academic surgery. }\end{array}$ \\
\hline Morton & 2007 & $\begin{array}{l}\text { Women and men on a } \\
\text { professional society or } \\
\text { journal editorial board }\end{array}$ & Survey & $\begin{array}{l}\text { To quantify the number of } \\
\text { women in this boards }\end{array}$ & $\begin{array}{l}\text { Women's representation on societies and editorial } \\
\text { boards does not always reflect their presence in } \\
\text { medical specialties. } 83 \% \text { of board members were men, } \\
\text { and occupied }>80 \% \text { of top leadership positions. }\end{array}$ \\
\hline Hoover & 2006 & & Editorial & $\begin{array}{l}\text { To identify factors behind } \\
\text { gender inequities in } \\
\text { academic surgery }\end{array}$ & $\begin{array}{l}\text { Underrepresentation of women at all levels of } \\
\text { academic surgery; importance of mentoring. }\end{array}$ \\
\hline Klingensmith & 2006 & $\begin{array}{l}\text { Members of the Associa- } \\
\text { tion for Surgical Educa- } \\
\text { tion }\end{array}$ & Cohort study & $\begin{array}{l}\text { To determine whether or } \\
\text { not educational scholarship } \\
\text { is a pathway to academic } \\
\text { promotion }\end{array}$ & $\begin{array}{l}\text { Overrepresentation of male in academic surgery ( } 82 \mathrm{vs} \\
18 \% \text { ). Women seek advanced training in educational } \\
\text { scholarship in greater proportions than men. } \\
\text { Academic promotion occurs for individuals with } \\
\text { focus on education. }\end{array}$ \\
\hline Mendoza & 2004 & $\begin{array}{l}\text { Members of the Associa- } \\
\text { tion of Surgical Education } \\
\text { and the Association of } \\
\text { Program directors in } \\
\text { Surgery }\end{array}$ & Survey & $\begin{array}{l}\text { To assess academic } \\
\text { preparation and scholarly } \\
\text { activity of educators in } \\
\text { surgical departments }\end{array}$ & $\begin{array}{l}\text { Professional educators provide support needed to } \\
\text { meet the growing demands and requirements of } \\
\text { surgical education. Predominance of women involved } \\
\text { in education. }\end{array}$ \\
\hline Risberg & 2003 & $\begin{array}{l}\text { Physicians involved in } \\
\text { medical teaching }\end{array}$ & $\begin{array}{l}\text { Prospective } \\
\text { cohort }\end{array}$ & $\begin{array}{l}\text { To investigate gender } \\
\text { awareness among physician } \\
\text { teachers }\end{array}$ & $\begin{array}{l}\text { There is an interaction between physician teachers' } \\
\text { gender and specialty. Male physicians from the } \\
\text { surgical group assessed gender less important than } \\
\text { female physicians in professional relationship. No } \\
\text { significant differences between specialty groups } \\
\text { among women. }\end{array}$ \\
\hline Flannery & 2002 & & Review & & $\begin{array}{l}\text { Difficulties for women to progress in academic } \\
\text { promotion. More women involved in clinical teaching. }\end{array}$ \\
\hline Jonasson & 2002 & $\begin{array}{l}\text { Members of several } \\
\text { American surgical } \\
\text { societies }\end{array}$ & Cohort study & $\begin{array}{l}\text { To assess the status of } \\
\text { women in leadership } \\
\text { positions in surgery }\end{array}$ & $\begin{array}{l}\text { Underrepresentation of women in the major Ameri- } \\
\text { can societies and organizations, and in higher levels of } \\
\text { academic departments of surgery. }\end{array}$ \\
\hline Tesch & 1995 & $\begin{array}{l}\text { American physician, } \\
\text { AAMC database }\end{array}$ & Survey & $\begin{array}{l}\text { To explain the fact that the } \\
\text { percentage of women } \\
\text { members of medical school } \\
\text { faculty with professor rank } \\
\text { is lower than men }\end{array}$ & $\begin{array}{l}\text { Women physician medical school faculty are } \\
\text { promoted more slowly than equal qualified men. }\end{array}$ \\
\hline
\end{tabular}

II. Gender differences in skills acquisition among undergraduate medical students learning surgery

Lee and colleagues tried to identify variables associated with clinical clerkship grades in a large survey, and found that females tend to obtain lower grades in internal medicine and surgery, whereas males got lower grades in obstetrics/gynecology and psychiatry. ${ }^{18}$
Male students are more exposed and perform surgical procedures significantly more often than female students, and working experience seems to enhance the surgical skills of medical students, but research experience may impair the learning of these procedures. The systematic use of logbooks seems to be useful for both male and female students. $^{19}$ 
When e-learning is used as a complement to traditional teaching methods in undergraduate surgical teaching, there are no significant gender differences in the utilization of the online program. Student utilization of the multimedia learning tool was not associated with improvements on final-year examination results. ${ }^{20,21}$

Lee and colleagues did not find objective differences in dexterity in students interested in surgical fields when compared with those interested in nonsurgical fields, ${ }^{22}$ whereas Elneel and colleagues found that right-handed males exhibited a greater level of ambidexterity than lefthanded males and right-handed females, and more efficient task performance as measured by execution time. ${ }^{23}$

The majority of the studies that investigate gender differences in surgical skills acquisition are related to laparoscopic skill acquisition in a simulator environment, and the results are contradictory. Some studies have shown that males tended to perform better than females in completing tasks that required the use of visual-spatial manipulation of the instruments within a simulated laparoscopic or endoscopic environment, ${ }^{24-29}$ whereas other studies have shown no difference in performance. ${ }^{28,30-35}$ Even though men completed the tasks in less time than women in some studies, there were no statistical difference between the genders in the number of errors and unnecessary movements. ${ }^{29}$ Despite that, women display initial lower performance, but respond to simulator training at least as well as men and reach parity with men's performance after training $^{24}$ (Table 2).

Table 2. Gender differences in skills acquisition of undergraduate medical students learning surgery

\begin{tabular}{|c|c|c|c|c|c|c|}
\hline Author & Year & Participants & $\begin{array}{l}\text { Number of } \\
\text { participants } \\
\text { male/female }\end{array}$ & Type of study & Study objective & Findings \\
\hline White & 2012 & $\begin{array}{l}4 \text { th year } \\
\text { medical } \\
\text { students and } \\
\text { 1st year } \\
\text { residents }\end{array}$ & $\begin{array}{l}\text { Students } 80 / 45 \\
\text { Residents } 40 / 16\end{array}$ & $\begin{array}{l}\text { Retrospective } \\
\text { analysis of } \\
\text { outcomes }\end{array}$ & $\begin{array}{l}\text { To investigate gender } \\
\text { difference in the acquisi- } \\
\text { tion of laparoscopic skills }\end{array}$ & $\begin{array}{l}\text { Women display initial lower performance, but } \\
\text { respond to training as well as men and reach } \\
\text { parity with men's performance after training. }\end{array}$ \\
\hline Lee & 2012 & $\begin{array}{l}\text { 3rd year } \\
\text { medical } \\
\text { students }\end{array}$ & $100(59 / 41)$ & Prospective & $\begin{array}{l}\text { To examine the impact of } \\
\text { innate manual dexterity } \\
\text { on the career interests of } \\
\text { medical students }\end{array}$ & $\begin{array}{l}5 \text { female interested in surgical fields vs } 16 \text { male. } \\
\text { No objective difference in dexterity in students } \\
\text { interested in surgical fields when compared with } \\
\text { those interested in nonsurgical fields. }\end{array}$ \\
\hline Thorson & 2012 & $\begin{array}{l}\text { 4th year } \\
\text { medical } \\
\text { students }\end{array}$ & $16 / 16$ & Prospective & $\begin{array}{l}\text { To investigate the } \\
\text { performance in laparos- } \\
\text { copy simulation of } \\
\text { students interested in } \\
\text { surgery, vs not, and } \\
\text { differences by gender }\end{array}$ & $\begin{array}{l}11 \text { male/ } 6 \text { females interested in surgery. Female } \\
\text { students have less innate abilities to laparoscopy. }\end{array}$ \\
\hline Kolozsvari & 2011 & $\begin{array}{l}\text { Medical } \\
\text { students }\end{array}$ & $32(19 / 13)$ & $\begin{array}{l}\text { Prospective, } \\
\text { intervention } \\
\text { study }\end{array}$ & $\begin{array}{l}\text { To evaluate the impact of } \\
\text { gender on the learning } \\
\text { curve for a fundamental } \\
\text { laparoscopic task }\end{array}$ & $\begin{array}{l}\text { Gender did not affect the learning curve for a } \\
\text { fundamental laparoscopic task, while interest in } \\
\text { surgery and perceptual abilities did influence } \\
\text { early performance. }\end{array}$ \\
\hline Szczepanik & 2010 & $\begin{array}{l}\text { Surgeons and } \\
\text { medical } \\
\text { students }\end{array}$ & $\begin{array}{l}17 \text { surgeons } \\
44 \text { students }\end{array}$ & Prospective & $\begin{array}{l}\text { To assess motor coordi- } \\
\text { nation skills in medical } \\
\text { students, surgical } \\
\text { residents and attending } \\
\text { surgeons }\end{array}$ & No gender differences in coordination skills. \\
\hline Adamczyk & 2009 & $\begin{array}{l}\text { 1st year } \\
\text { medical } \\
\text { students }\end{array}$ & $\begin{array}{l}850 \text { (Unknown } \\
\text { proportion } \\
\text { male/female) }\end{array}$ & $\begin{array}{l}\text { Survey and } \\
\text { retrospective } \\
\text { review of } \\
\text { examination } \\
\text { results }\end{array}$ & $\begin{array}{l}\text { To investigate how } \\
\text { students use multimedia } \\
\text { tools to support their } \\
\text { learning during a gross } \\
\text { anatomy dissection } \\
\text { course }\end{array}$ & $\begin{array}{l}45 \% \text { of male and } 33 \% \text { of female students used } \\
\text { the multimedia-learning tool, both groups found } \\
\text { it equally valuable. No gender differences in } \\
\text { performances. No significant correlation } \\
\text { between the use of the multimedia learning tool } \\
\text { and the exam performance of students. }\end{array}$ \\
\hline Shane & 2008 & $\begin{array}{l}4 \text { th year } \\
\text { medical } \\
\text { students and } \\
\text { 1st year } \\
\text { residents }\end{array}$ & $26(17 / 9)$ & Prospective & $\begin{array}{l}\text { To investigate if previous } \\
\text { video game experience } \\
\text { facilitates acquire new } \\
\text { surgical skills }\end{array}$ & $\begin{array}{l}\text { Previous video game experience shortens time to } \\
\text { achieve proficiency on two tasks on a validated } \\
\text { surgical simulator. Women perform worse than } \\
\text { men. }\end{array}$ \\
\hline Madan & 2008 & $\begin{array}{l}\text { Preclinical } \\
\text { medical } \\
\text { students }\end{array}$ & 51 & Prospective & $\begin{array}{l}\text { To investigate if baseline } \\
\text { laparoscopic skills scores } \\
\text { could be predicted in an } \\
\text { inanimate box trainers } \\
\text { and virtual-reality trainers }\end{array}$ & $\begin{array}{l}\text { No gender differences in box trainer, male } \\
\text { performed better in virtual-reality trainer. }\end{array}$ \\
\hline
\end{tabular}


Table 2 (Cont.)

\begin{tabular}{|c|c|c|c|c|c|c|}
\hline Author & Year & Participants & $\begin{array}{l}\text { Number of } \\
\text { participants } \\
\text { male/female }\end{array}$ & Type of study & Study objective & Findings \\
\hline Elneel & 2008 & $\begin{array}{l}\text { Medical } \\
\text { students }\end{array}$ & 50 & Prospective & $\begin{array}{l}\text { To determine innate } \\
\text { dexterity and ambidexter- } \\
\text { ity across handedness and } \\
\text { gender }\end{array}$ & $\begin{array}{l}\text { Right-handed males exhibited a greater level of } \\
\text { ambidexterity than left-handed males and right- } \\
\text { handed females, and more-efficient task } \\
\text { performance as measured by execution time. }\end{array}$ \\
\hline Lee & 2007 & $\begin{array}{l}\text { 3rd and } 4 \text { th } \\
\text { year medical } \\
\text { students }\end{array}$ & $2395(949 / 1328)$ & Survey & $\begin{array}{l}\text { To identify variables } \\
\text { associated with clinical } \\
\text { clerkship grades }\end{array}$ & $\begin{array}{l}\text { Lower grades for females in internal medicine } \\
\text { and surgery, lower grades for males in ob/gyn } \\
\text { and psychiatry. }\end{array}$ \\
\hline Rosenthal & 2006 & $\begin{array}{l}\text { Medical } \\
\text { students }\end{array}$ & $20(12 / 8)$ & $\begin{array}{l}\text { Prospective, } \\
\text { intervention } \\
\text { study }\end{array}$ & $\begin{array}{l}\text { To evaluate the perfor- } \\
\text { mance curves on } \\
\text { repetitive trials for a } \\
\text { laparoscopic task on a } \\
\text { simulator, and the inter- } \\
\text { individual differences } \\
\text { after training }\end{array}$ & $\begin{array}{l}\text { The performance curves for some of the } \\
\text { simulator measurements were very close to } \\
\text { logarithmic curves, and there were significant } \\
\text { inter-individual differences in performance at } \\
\text { the end of the repetitive trials. No significant } \\
\text { gender differences observed. }\end{array}$ \\
\hline Donnon & 2005 & $\begin{array}{l}\text { 1st and } 2 \text { nd } \\
\text { year medical } \\
\text { students }\end{array}$ & $42(21 / 21)$ & $\begin{array}{l}\text { Randomized } \\
\text { control }\end{array}$ & $\begin{array}{l}\text { To study the effect, } \\
\text { between genders, of } \\
\text { cognitive imaging as a } \\
\text { teaching method in } \\
\text { learning a surgical } \\
\text { technique. }\end{array}$ & $\begin{array}{l}\text { Males tended to perform better than females in } \\
\text { completing tasks that required the use of visual- } \\
\text { spatial manipulation of the instruments within a } \\
\text { simulated laparoscopic environment. }\end{array}$ \\
\hline Madan & 2005 & $\begin{array}{l}\text { 1st and } 2 \text { nd } \\
\text { year medical } \\
\text { students }\end{array}$ & 68 & $\begin{array}{l}\text { Prospective, } \\
\text { intervention } \\
\text { study }\end{array}$ & $\begin{array}{l}\text { To explore if baseline } \\
\text { laparoscopic surgery skills } \\
\text { can be predicted. }\end{array}$ & $\begin{array}{l}\text { No gender differences in laparoscopic skills. It is } \\
\text { difficult to predict baseline laparoscopic surgery } \\
\text { skills. }\end{array}$ \\
\hline Healy & 2005 & $\begin{array}{l}\text { Medical } \\
\text { students }\end{array}$ & $148(48 / 90)$ & $\begin{array}{l}\text { Prospective } \\
\text { observational } \\
\text { study }\end{array}$ & $\begin{array}{l}\text { To evaluate the utilization } \\
\text { of the web-based program }\end{array}$ & $\begin{array}{l}\text { Electronic learning complements traditional } \\
\text { teaching methods in undergraduate surgical } \\
\text { teaching. No significant gender differences in } \\
\text { the utilization of online access. Student } \\
\text { utilization of the program was not associated } \\
\text { with improvements on final year examination } \\
\text { results. }\end{array}$ \\
\hline Enochsoon & 2004 & $\begin{array}{l}\text { Medical } \\
\text { students }\end{array}$ & $17(8 / 9)$ & $\begin{array}{l}\text { Prospective, } \\
\text { intervention } \\
\text { study }\end{array}$ & $\begin{array}{l}\text { To investigate factors that } \\
\text { can predict performance } \\
\text { in simulated gastroscopy }\end{array}$ & $\begin{array}{l}\text { No significant gender-specific differences in the } \\
\text { performance of the simulator, although there } \\
\text { was a trend toward men performing better in } \\
\text { two of the metrics, time of endoscopy, and } \\
\text { efficiency of screening. }\end{array}$ \\
\hline Grantcharov & 2003 & $\begin{array}{l}\text { Novel } \\
\text { residents }\end{array}$ & $25(18 / 7)$ & $\begin{array}{l}\text { Prospective, } \\
\text { intervention } \\
\text { study }\end{array}$ & $\begin{array}{l}\text { To identify factors } \\
\text { influencing surgeons' } \\
\text { performance in a } \\
\text { computer simulator for } \\
\text { laparoscopy }\end{array}$ & $\begin{array}{l}\text { Men completed the tasks in less time than } \\
\text { women, but there was no statistical difference } \\
\text { between the genders in the number of errors and } \\
\text { unnecessary movements. }\end{array}$ \\
\hline Helenius & 2002 & $\begin{array}{l}\text { Last year } \\
\text { medical } \\
\text { students }\end{array}$ & $404(138 / 266)$ & Survey & $\begin{array}{l}\text { To gather information on } \\
\text { the basic surgical skills of } \\
\text { graduating medical } \\
\text { students and to establish } \\
\text { the factors influencing the } \\
\text { students' competence }\end{array}$ & $\begin{array}{l}\text { Final-year medical students have good theoreti- } \\
\text { cal knowledge of basic surgical procedures, but } \\
\text { the successful performance rates range from } 1 \text { to } \\
90 \% \text {. Males performed surgical procedures } \\
\text { significantly more often than females. Working } \\
\text { experience enhanced the surgical skills, but } \\
\text { research experience impaired the learning of the } \\
\text { procedures. The systematic use of logbooks } \\
\text { seems to be useful. }\end{array}$ \\
\hline Mehrabi & 2000 & $\begin{array}{l}4 \text { th year } \\
\text { medical } \\
\text { students }\end{array}$ & $103(78 / 72)$ & $\begin{array}{l}\text { Prospective, } \\
\text { intervention } \\
\text { study }\end{array}$ & $\begin{array}{l}\text { To develop and evaluate a } \\
\text { Computer Based Training } \\
\text { (CBT) program for } \\
\text { student }\end{array}$ & $\begin{array}{l}\text { No gender difference in the outcome. CBT } \\
\text { modules are an appropriate future teaching and } \\
\text { learning system. }\end{array}$ \\
\hline
\end{tabular}


Burgos \& Josephson Gender differences in learning and teaching of surgery

Table 3. Gender differences in undergraduate medical students learning surgery: attitudes and perceptions

\begin{tabular}{|c|c|c|c|c|c|c|}
\hline Author & Year & Participants & $\begin{array}{l}\text { Number of } \\
\text { participants } \\
\text { male/female }\end{array}$ & Type of study & Study objective & Findings \\
\hline \multicolumn{7}{|l|}{ Attitudes } \\
\hline Jack & 2010 & $\begin{array}{l}\text { Surgical faculty, } \\
\text { residents, and } \\
\text { medical students }\end{array}$ & $\begin{array}{l}61 \text { Faculty } \\
96 \text { Residents } 183 \\
\text { Medical students } \\
(90 / 93)\end{array}$ & Survey & $\begin{array}{l}\text { To assessed learning } \\
\text { styles in medicine and to } \\
\text { compare teaching and } \\
\text { learning preferences }\end{array}$ & $\begin{array}{l}\text { Medical students preferred converging } \\
\text { learning ( } 42 \%) \text { and cluster } 4 \text { teaching ( } 35 \%) \text {, } \\
\text { no gender differences observed, no differ- } \\
\text { ences regarding specialty. } 24 \% \text { of students } \\
\text { interested in surgery, no specification of } \\
\text { gender. }\end{array}$ \\
\hline Snelling & 2003 & $\begin{array}{l}\text { 1st year medical } \\
\text { and dental } \\
\text { students }\end{array}$ & $467(173 / 294)$ & Survey & $\begin{array}{l}\text { To investigate how } \\
\text { attitudes toward dissec- } \\
\text { tion vary with gender and } \\
\text { ethnicity }\end{array}$ & $\begin{array}{l}\text { Females were consistently more concerned } \\
\text { about the physical aspects of dissection } \\
\text { whereas there were fewer gender differences } \\
\text { in the emotional responses. }\end{array}$ \\
\hline \multicolumn{7}{|c|}{ Perceptions } \\
\hline Babaria & 2012 & $\begin{array}{l}\text { 3rd year medical } \\
\text { students }\end{array}$ & $12(0 / 12)$ & Interview & $\begin{array}{l}\text { To investigate the } \\
\text { spectrum of experiences } \\
\text { of sexual harassment and } \\
\text { gender discrimination } \\
\text { and the effect on the } \\
\text { professional identity of } \\
\text { female students }\end{array}$ & $\begin{array}{l}\text { Participants quickly learned how to confront } \\
\text { and respond to inappropriate behavior. They } \\
\text { did not feel equipped to respond to the } \\
\text { unprofessional behavior of male supervisors, } \\
\text { resulting in feelings of guilt and resignation } \\
\text { over time that such events would be a part of } \\
\text { their professional identity. }\end{array}$ \\
\hline Lempp & 2006 & Medical students & $36(15 / 21)$ & Interview & $\begin{array}{l}\text { To examine students' } \\
\text { experiences and percep- } \\
\text { tions in relation to gender } \\
\text { and ethnicity }\end{array}$ & $\begin{array}{l}\text { No gender differences training experiences. } \\
\text { Males experienced gender difficulties during } \\
\text { the obstetrics and gynecology rotation. } \\
\text { Students report gender-related distinctions } \\
\text { consistent with traditional gender stereo- } \\
\text { types. }\end{array}$ \\
\hline Stratton & 2005 & $\begin{array}{l}4 \text { th year medical } \\
\text { students }\end{array}$ & $1027(549 / 478)$ & Survey & $\begin{array}{l}\text { To examine the role of } \\
\text { gender discrimination } \\
\text { and sexual harassment in } \\
\text { medical students' choice } \\
\text { of specialty and residency } \\
\text { program }\end{array}$ & $\begin{array}{l}\text { Women exposed indicated that gender } \\
\text { discrimination and sexual harassment } \\
\text { influenced their specialty choices. Men } \\
\text { choosing obstetrics and gynecology experi- } \\
\text { enced such behavior. Women choosing } \\
\text { general surgery were most likely to experi- } \\
\text { ence gender discrimination and sexual } \\
\text { harassment during residency selection. }\end{array}$ \\
\hline Cochran & 2003 & $\begin{array}{l}\text { 3rd year medical } \\
\text { students }\end{array}$ & 93 & Survey & $\begin{array}{l}\text { To evaluate the impact of } \\
\text { a general surgery } \\
\text { clerkship on medical } \\
\text { students' perceptions of } \\
\text { surgeons and surgical } \\
\text { careers }\end{array}$ & $\begin{array}{l}\text { Medical student perceptions of surgeons and } \\
\text { surgical careers generally improve during the } \\
\text { surgical clerkship, but students' impressions } \\
\text { of surgeons' collegial behavior and commit- } \\
\text { ment to teaching deteriorate significantly } \\
\text { during the surgical clerkship. }\end{array}$ \\
\hline Neumayer & 2002 & $\begin{array}{l}\text { Final year female } \\
\text { medical students }\end{array}$ & $305(0 / 305)$ & Survey & $\begin{array}{l}\text { To identify if the } \\
\text { proportion of women } \\
\text { surgeons on the faculty } \\
\text { influences the student's } \\
\text { perceptions about women } \\
\text { surgeons or their career } \\
\text { choice }\end{array}$ & $\begin{array}{l}\text { Women medical students' perception of } \\
\text { women surgeons' career satisfaction did not } \\
\text { appear to be affected by the proportion of } \\
\text { women surgeons on the faculty. Their choice } \\
\text { of surgery as a career was strongly associated } \\
\text { with a higher proportion of women on the } \\
\text { surgical faculty. }\end{array}$ \\
\hline Field & 1996 & $\begin{array}{l}\text { 1st and 5th year } \\
\text { medical students }\end{array}$ & $?$ & Interview & $\begin{array}{l}\text { To investigate if gender } \\
\text { affects future career } \\
\text { choices and the ability to } \\
\text { reach career goals }\end{array}$ & $\begin{array}{l}\text { Females were seen as being disadvantaged } \\
\text { both in terms of career choice and their } \\
\text { ability to achieve career goals. Female } \\
\text { students were more likely to suffer discrimi- } \\
\text { nation in specialties as surgery, and to be } \\
\text { dissuaded from pursuing a career in that } \\
\text { specialty. }\end{array}$ \\
\hline
\end{tabular}


III. Gender differences in attitudes and perceptions among undergraduate medical students learning surgery

\section{Attitudes}

Snelling and colleagues investigate how attitudes toward dissection vary with gender and ethnicity. Females were consistently more concerned about the physical aspects of dissection whereas there were fewer gender differences in the emotional responses. ${ }^{36}$

\section{Perceptions}

Experiences of sexual harassment and gender discrimination have an effect on the professional identity formation and specialty choice of medical students. Female students choosing general surgery were those most likely to experience gender discrimination and sexual harassment during residency selection, and to be dissuaded from pursuing a career in that specialty. ${ }^{37,38}$ Female medical students do not feel equipped to respond to the unprofessional behavior of male supervisors, resulting in feelings of guilt and resignation over time that such events would be a part of their professional identity. ${ }^{39}$

Lempp and Seale ${ }^{40}$ performed semi-structured interviews of 36 medical students throughout their medical education. Students did not report any gender-related differences in their training, although they used genderrelated terms in their answers consistent with traditional gender stereotypes. A majority stated that surgery was dominated by men, reporting that the specialty required physical strength, competitiveness, unusually hard work and long working hours in order to succeed. Nevertheless, four female students (of 21) and four male students (of 15) were considering surgery as a career option. Most students (23/36) identified certain specialties as being 'suitable' for women, these being (in descending order of frequency) obstetrics and gynecology, general practice, pediatrics and palliative care. Eleven students (7 females, 4 males) used the word 'sacrifice' in relation to women and their medical career, for example in having to limit either their career or their family aspirations, but none used this remark to describe the careers of male doctors. ${ }^{40}$

The perception of women medical students of the career satisfaction of women surgeons did not appear to be affected by the proportion of women surgeons on the faculty at their medical school. Their choice of surgery as a career was strongly associated with a higher proportion of women on the surgical faculty ${ }^{41}$ (Table 3 ).

$I V$. Gender and personality differences in undergraduate medical students' interest in pursuing a career in surgery

Several of the studies have shown that gender has the greatest impact on specialty choice, with males choosing medicine, surgery, orthopedics and urology and females choosing obstetrics, pediatrics, anesthesiology, primary care and ophthalmology. ${ }^{42-48}$
There is an overall declining popularity for surgical careers among both male and female students. ${ }^{7,49-52}$ On the other hand, other authors found general surgery to be the second preferred choice for men and the third preferred choice for women, with a total interest of $21 \%$ of the students. ${ }^{43}$

Gender significantly influences the choice of surgery as a career, with a consistently lower proportion of women compared to men interested in pursuing a surgical career in different studies, in a range of $15-42 \%$ for male students and 2-29\% for female students. ${ }^{42,46,49,54-64}$ Only two studies have shown that gender has no independent influence on choosing surgery as a career. ${ }^{44,45}$

Male gender, updated preference, peer tutoring and selective training were the most significant predictors in the pathway to choosing surgery ${ }^{46}$ (Table 4 ).

Gender, prestige, career opportunities, direct patient care, immediate intervention, and personal interest are common positive influential factors for choosing a career in surgery. ${ }^{7,47}$ Gender discrimination, concerns about lifestyle, family considerations, increased stress and work hours and sacrifice of personal time are the most common negative factors to the pursuit of a career in surgery. ${ }^{7,51,54}$

Several authors have investigated the relationship between personality and specialty interest. Students interested in 'surgical' specialties obtain higher scores on 'impulsive sensation seeking' 'aggression-hostility' and 'sociability' scales and lower scores on a measure of 'neuroticismanxiety'. Male students had significantly higher scores on the 'impulsive sensation seeking', and surgery was the single most popular specialty among male students. ${ }^{48,49}$

Coulston and colleagues found that significantly fewer females than males rated surgery highly likely as a career. They also found that females interested in surgery had higher neuroticism and agreeableness scores, and placed greater importance on the ability to help people, and less importance on prestige and financial reward compared to males interested in surgery. Compared to males not interested in surgery, females interested in surgery had higher Openness scores, and placed greater importance on ability to help people, interesting and challenging work, and less importance on lifestyle. Also, females interested in surgery had lower Agreeableness scores, and placed greater importance on prestige and less importance on lifestyle compared to females not interested in surgery. Common findings were that surgeons compared to non- surgeons are more tough-minded, less patient-oriented and less empathic, and may be a function of the prevalence of males in surgery. ${ }^{50}$

Professional attitudes in particular patient centeredness were shown by Batenburg and colleagues to be related to specialty preference in the final year of graduate medical training and specialty as a career choice: general practice trainees showed more patient-centeredness than surgery trainees. Gender was not related to patient-centeredness. ${ }^{51}$ 
Significant gender differences were found when comparing empathy levels in medical students at different levels of education, on "emotional intelligence", "empathy" and the "Utilization of Emotion" subscale, with females scoring higher than males on all three scales. There were no significant gender differences in end-of-year marks in any of the 3-year groups, with male empathy scores increasing between years 1 and 2, while female scores declined. ${ }^{52}$

Frantsve and colleagues examined the effects of the applicant's personality and gender on faculty rankings and matching to surgical residency program. Male applicants were more likely than female applicants to enjoy teamwork and assume a submissive role when interacting with authority figures. The faculty interviewers perceived female applicants as less likely to effectively cope with stress. They also found that female applicants might be less likely than males to be as friendly and deferent in their interactions with male authority figures. When compared to the general population, however, female applicants did not demonstrate evidence of difficulties with stress management ${ }^{53}$ (Table 5).

Table 4. Gender differences in undergraduate medical students' career intentions in surgery

\begin{tabular}{|c|c|c|c|c|c|c|}
\hline Author & Year & Participants & $\begin{array}{l}\text { Number of articles/ } \\
\text { participants } \\
\text { male/female }\end{array}$ & $\begin{array}{l}\text { Type of } \\
\text { study }\end{array}$ & Study objective & Findings \\
\hline $\mathrm{Yu}$ & 2012 & $\begin{array}{l}\text { Medical } \\
\text { students }\end{array}$ & 17 articles & Review & $\begin{array}{l}\text { To summarize the factors } \\
\text { influencing female medical } \\
\text { students when choosing a } \\
\text { career in surgery }\end{array}$ & $\begin{array}{l}\text { No gender differences in concerns about } \\
\text { lifestyle and family priorities when consider- } \\
\text { ing a career in surgery. Gender discrimina- } \\
\text { tion and bias as a consistently and significant } \\
\text { career deterrent reported by female medical } \\
\text { students. }\end{array}$ \\
\hline Fitzgerald & 2012 & $\begin{array}{l}\text { Newly } \\
\text { graduates }\end{array}$ & $280(78 / 130)$ & Survey & $\begin{array}{l}\text { To investigate the perceptions } \\
\text { of surgical careers among } \\
\text { recent medical school } \\
\text { graduates }\end{array}$ & $\begin{array}{l}42 \% \text { males vs } 25 \% \text { females interested in a } \\
\text { career in surgery. Reported negative } \\
\text { attitudes toward women among the surgical } \\
\text { teams. } 59 \% \text { of male and } 68 \% \text { of female } \\
\text { respondents believed surgery was not a } \\
\text { career welcoming women. }\end{array}$ \\
\hline Bhat & 2012 & $\begin{array}{l}\text { Interns/ } \\
\text { Newly } \\
\text { graduated }\end{array}$ & $250(130 / 120)$ & Survey & $\begin{array}{l}\text { To investigate the factors } \\
\text { influencing the preferences of } \\
\text { medical graduates for } \\
\text { specialization }\end{array}$ & $\begin{array}{l}\text { Gender significantly influenced specialty } \\
\text { choice with males choosing medicine and } \\
\text { surgery and females choosing obstetrics and } \\
\text { pediatrics. Factors which influenced } \\
\text { specialty choice included job satisfaction, } \\
\text { income, lifestyle friendliness and career } \\
\text { prospects. }\end{array}$ \\
\hline Zarebaczan & 2011 & $\begin{array}{l}\text { 3rd and } 4 \text { th } \\
\text { year students }\end{array}$ & $505(225 / 280)$ & Survey & $\begin{array}{l}\text { To evaluate if the limitation of } \\
\text { working hours increased } \\
\text { medical students' interest } \\
\text { in pursuing a career in surgery }\end{array}$ & $\begin{array}{l}\text { The } 80 \text {-h work week has not improved } \\
\text { medical students' interests in surgery. } 19 \% \\
\text { males vs } 7.6 \% \text { females were interested in } \\
\text { surgery. }\end{array}$ \\
\hline $\begin{array}{l}\text { Maseghe } \\
\text { Mwachaka }\end{array}$ & 2010 & $\begin{array}{l}\text { Medical } \\
\text { students }\end{array}$ & 385 & Survey & $\begin{array}{l}\text { To assess specialty preferences } \\
\text { and factors influencing } \\
\text { specialty choices among male } \\
\text { and female medical students }\end{array}$ & $\begin{array}{l}\text { Significantly more males preferred surgery } \\
\text { than females, who mainly selected pediatrics. } \\
\text { Male students considered prestige in a } \\
\text { specialty, female students considered ease of } \\
\text { raising a family and gender distribution in } \\
\text { the specialty. }\end{array}$ \\
\hline Lefèvre & 2010 & $\begin{array}{l}\text { 6th year } \\
\text { medical } \\
\text { students }\end{array}$ & $1742(662 / 1080)$ & Survey & $\begin{array}{l}\text { To analyze the aspirations and } \\
\text { personal motivations behind } \\
\text { the choice of surgical special- } \\
\text { ties }\end{array}$ & $\begin{array}{l}\text { Gender as a determining factor to choose } \\
\text { surgery: } 44 \% \text { of men vs } 29 \% \text { of women. } \\
\text { Feminization, life style and income are the } \\
\text { principal factors influencing the choice of } \\
\text { the type of surgical specialization. }\end{array}$ \\
\hline Deedar & 2010 & $\begin{array}{l}\text { Medical } \\
\text { students }\end{array}$ & 39 articles & Review & $\begin{array}{l}\text { To explore global trends } \\
\text { related to medical student } \\
\text { interest in surgical careers, and } \\
\text { to identify factors influencing } \\
\text { the choice of surgery as a } \\
\text { career }\end{array}$ & $\begin{array}{l}\text { Overall declining popularity of surgery, with } \\
\text { the exception of Greece, Jordan, and Nigeria, } \\
\text { and a relative rebound seen in US. Direct } \\
\text { patient care, immediate intervention, and } \\
\text { personal interest as common positive } \\
\text { influential factors. Family considerations, } \\
\text { increased stress and work hours, sacrifice of } \\
\text { personal time, and lack of (or negative) role } \\
\text { models as common negative factors. }\end{array}$ \\
\hline Are & 2009 & $\begin{array}{l}\text { 4th year } \\
\text { students }\end{array}$ & $140(67 / 73$ & Survey & $\begin{array}{l}\text { To describe the attitudes of } \\
\text { fourth-year medical students } \\
\text { towards general surgery. }\end{array}$ & $\begin{array}{l}10 \% \text { of students chose surgery ( } 10 \text { males and } \\
5 \text { females) Only } 16 \% \text { of the faculty depart- } \\
\text { ment were female. }\end{array}$ \\
\hline
\end{tabular}


Table 4 (Cont.)

\begin{tabular}{|c|c|c|c|c|c|c|}
\hline Author & Year & Participants & $\begin{array}{l}\text { Number of articles/ } \\
\text { participants } \\
\text { male/female }\end{array}$ & $\begin{array}{l}\text { Type of } \\
\text { study }\end{array}$ & Study objective & Findings \\
\hline Maggiori & 2009 & $\begin{array}{l}\text { Medical } \\
\text { graduates }\end{array}$ & $929(291 / 638)$ & $\begin{array}{l}\text { Cohort } \\
\text { study }\end{array}$ & $\begin{array}{l}\text { To analyze the choices of } \\
\text { specialties of interns }\end{array}$ & $\begin{array}{l}21 \% \text { interested in surgery, more male }(41 \%) \\
\text { than female }(22 \%) .\end{array}$ \\
\hline Soethout & 2008 & $\begin{array}{l}\text { 1st- } 5 \text { th year } \\
\text { students }\end{array}$ & $3102(1055 / 2047)$ & Survey & $\begin{array}{l}\text { To investigate the association } \\
\text { between biographical } \\
\text { characteristics and academic } \\
\text { achievement with preferences } \\
\text { for specialty }\end{array}$ & $\begin{array}{l}\text { Overall, more males interested in surgery } \\
\text { than females. Medical background of the } \\
\text { parents and gender are positively associated } \\
\text { with a preference for a career. }\end{array}$ \\
\hline Copmton & 2008 & $\begin{array}{l}\text { Medical } \\
\text { students }\end{array}$ & $942(501 / 441)$ & Survey & $\begin{array}{l}\text { To describe patterns of change } \\
\text { in specialty interests during } \\
\text { medical school }\end{array}$ & $\begin{array}{l}\text { Pediatrics }(20 \%) \text { and surgery }(18 \%) \text { the most } \\
\text { common specialty choices among students. } \\
\text { More women interested in primary care. } \\
\text { Prestige more important for men than } \\
\text { women }(48 \% \text { vs } 36 \%) \text {. }\end{array}$ \\
\hline Khader & 2008 & $\begin{array}{l}\text { 2nd, } 4 \text { th and } \\
6 \text { th year } \\
\text { students }\end{array}$ & $440(287 / 158)$ & $\begin{array}{l}\text { Cross- } \\
\text { sectional } \\
\text { study }\end{array}$ & $\begin{array}{l}\text { To investigate the career } \\
\text { preferences of medical } \\
\text { students at Jordan University }\end{array}$ & $\begin{array}{l}\text { Surgery as the preferred specialty by male } \\
\text { students, obstetrics and gynecology by } \\
\text { female students. }\end{array}$ \\
\hline Scott & 2008 & $\begin{array}{l}\text { 1st year } \\
\text { medical } \\
\text { students }\end{array}$ & 2168 & Survey & $\begin{array}{l}\text { To identify the interest in } \\
\text { surgery and the factors that } \\
\text { influence a student's interest in } \\
\text { pursuing a surgical career }\end{array}$ & $\begin{array}{l}\text { Declining preference for surgical careers } \\
\text { among students, with only } 21 \%(441,238 \\
\text { males/203 females) of students interested. } \\
\text { Male students interested in surgery were } \\
\text { more hospital-oriented and less social } \\
\text { orientated than female students. }\end{array}$ \\
\hline Tambyraja & 2008 & $\begin{array}{l}\text { Final year } \\
\text { medical } \\
\text { students }\end{array}$ & $193(75 / 118)$ & Survey & $\begin{array}{l}\text { To examine the attitudes of } \\
\text { students to surgical training } \\
\text { and their career intentions. }\end{array}$ & $\begin{array}{l}53 \% \text { of male students consider a career in } \\
\text { surgery, } 35 \% \text { of female do. }\end{array}$ \\
\hline Bamboolal & 2007 & $\begin{array}{l}\text { 1st year } \\
\text { medical } \\
\text { students }\end{array}$ & $136(58 / 78)$ & Survey & $\begin{array}{l}\text { To determine factors that } \\
\text { influence career choice among } \\
\text { 1st-year medical students. }\end{array}$ & $\begin{array}{l}\text { Declining preferences for surgical careers } \\
\text { among males and females students: } 19 \% \text { of } \\
\text { the students chose surgery (not specify by } \\
\text { gender). }\end{array}$ \\
\hline Nohr & 2007 & $\begin{array}{l}\text { Medical } \\
\text { graduates } \\
\text { applying for } \\
\text { residency }\end{array}$ & 1920 & $\begin{array}{l}\text { Cohort } \\
\text { study }\end{array}$ & $\begin{array}{l}\text { To describe differences in } \\
\text { specialty choices and qualifica- } \\
\text { tions between male and female } \\
\text { physicians at the start of their } \\
\text { residency in Denmark 1998- } \\
2003\end{array}$ & $\begin{array}{l}\text { Gender differences in specialty choice and in } \\
\text { the way men and women qualify for } \\
\text { residency: women achieved higher points for } \\
\text { clinical qualification and theoretical courses, } \\
\text { while men achieved higher points for } \\
\text { scientific and pedagogical qualification. Most } \\
\text { of residents in orthopedic surgery were male, } \\
\text { in psychiatry or obstetrics female. }\end{array}$ \\
\hline
\end{tabular}

\begin{tabular}{|c|c|c|c|c|c|}
\hline $\begin{array}{l}\text { Buddeberg- } \\
\text { Fischer }\end{array}$ & 2006 & $\begin{array}{l}\text { Medical } \\
\text { graduates }\end{array}$ & $522(241 / 281)$ & $\begin{array}{l}\text { Prospec- } \\
\text { tive } \\
\text { cohort }\end{array}$ & $\begin{array}{l}\text { To investigate the influence of } \\
\text { gender, personality traits, } \\
\text { career motivation and life goal } \\
\text { aspirations on the choice of } \\
\text { medical specialty }\end{array}$ \\
\hline
\end{tabular}

\begin{tabular}{|c|c|c|c|c|c|c|}
\hline Huda & 2006 & $\begin{array}{l}\text { Final year } \\
\text { students }\end{array}$ & 232 & Survey & $\begin{array}{l}\text { To identify the career and } \\
\text { gender preferences of the final } \\
\text { year medical students }\end{array}$ & $\begin{array}{l}21 \% \text { students chose surgery, general surgery } \\
\text { being the } 2 \text { nd preferred for men and } 3 r d \\
\text { preferred choice for women. }\end{array}$ \\
\hline Sanfey & 2006 & $\begin{array}{l}\text { Medical } \\
\text { students }\end{array}$ & $1300(680 / 620)$ & $\begin{array}{l}\text { Web- } \\
\text { based } \\
\text { survey }\end{array}$ & $\begin{array}{l}\text { To investigate if the increased } \\
\text { enrollment of female medical } \\
\text { students and different } \\
\text { priorities of the current } \\
\text { generation of students would } \\
\text { have influence on the } \\
\text { declining interest in surgical } \\
\text { careers }\end{array}$ & $\begin{array}{l}35 \% \text { of women ( } 3 \% \text { men) were discouraged } \\
\text { by a lack of female role models. More male } \\
\text { than female students interested in surgery } \\
\text { agreed that their skill sets were compatible } \\
\text { with surgical careers ( } 30 \% \text { men vs } 24 \% \\
\text { women). The decision to have a family had } \\
\text { bigger influence for women than men, but } \\
\text { family and lifestyle priorities were also } \\
\text { important to male students. }\end{array}$ \\
\hline Sobral & 2006 & $\begin{array}{l}\text { Medical } \\
\text { graduates }\end{array}$ & $578(318 / 260)$ & $\begin{array}{l}\text { Cohort } \\
\text { study }\end{array}$ & $\begin{array}{l}\text { To examine the differential } \\
\text { impact of person-based and } \\
\text { program-related features on } \\
\text { graduates' dichotomous choice } \\
\text { between surgical or non- } \\
\text { surgical specialties. }\end{array}$ & $\begin{array}{l}\text { Declining preferences for surgical careers } \\
\text { among males and females students: only } 23 \% \\
\text { students choosing surgery, } 26 \% \text { of them } \\
\text { female. Male sex, updated preference, peer } \\
\text { tutoring and selective training were the most } \\
\text { significant predictors in the pathway to } \\
\text { choose surgery. }\end{array}$ \\
\hline
\end{tabular}


Burgos \& Josephson Gender differences in learning and teaching of surgery

Table 4 (Cont.)

\begin{tabular}{|c|c|c|c|c|c|c|}
\hline Author & Year & Participants & $\begin{array}{l}\text { Number of articles/ } \\
\text { participants } \\
\text { male/female }\end{array}$ & $\begin{array}{l}\text { Type of } \\
\text { study }\end{array}$ & Study objective & Findings \\
\hline Harris & 2005 & $\begin{array}{l}\text { Medical } \\
\text { graduates }\end{array}$ & 4259 & Survey & $\begin{array}{l}\text { To identify the relative } \\
\text { importance of extrinsic } \\
\text { determinants of doctors' } \\
\text { choice of specialty. }\end{array}$ & $\begin{array}{l}\text { Factors of particular importance to women, } \\
\text { compared with men, were "appraisal of } \\
\text { domestic circumstances", "hours of work" } \\
\text { and "opportunity to work flexible hours". }\end{array}$ \\
\hline Cochran & 2005 & $\begin{array}{l}\text { 4th year } \\
\text { medical } \\
\text { students }\end{array}$ & $408(214 / 189)$ & $\begin{array}{l}\text { Cross- } \\
\text { sectional } \\
\text { internet } \\
\text { survey }\end{array}$ & $\begin{array}{l}\text { To analyze characteristics of } \\
\text { general surgery residency and } \\
\text { practice and their influence on } \\
\text { student interest in surgical } \\
\text { careers }\end{array}$ & $\begin{array}{l}\text { Medical students who choose surgical } \\
\text { careers are not deterred by a negative } \\
\text { perception of lifestyle and workload } \\
\text { considerations. Mentoring and personality } \\
\text { fit are central in specialty selection. Surgery } \\
\text { selected by } 9 \% \text {, with similar proportion } \\
\text { male/female. }\end{array}$ \\
\hline Ek & 2005 & $\begin{array}{l}\text { Final year } \\
\text { medical } \\
\text { students }\end{array}$ & $251(126 / 125)$ & Survey & $\begin{array}{l}\text { To determine the views of final } \\
\text { year medical students in } \\
\text { Melbourne regarding both } \\
\text { undergraduate surgical } \\
\text { teaching and the students' } \\
\text { career aspirations. }\end{array}$ & $\begin{array}{l}\text { Male students were more likely to be } \\
\text { interested in surgery. } 57 \% \text { of female } \\
\text { respondents felt discouraged from pursuing } \\
\text { a surgical career and } 99 \% \text { of these women } \\
\text { reported lifestyle/family factors as the main } \\
\text { reason, with a further } 72 \% \text { identifying a lack } \\
\text { of female role models. }\end{array}$ \\
\hline Wendell & 2003 & $\begin{array}{l}\text { Medical } \\
\text { graduates }\end{array}$ & $120(48 / 54)$ & Survey & $\begin{array}{l}\text { To evaluate factors affecting } \\
\text { the choice of a surgical career } \\
\text { among gender }\end{array}$ & $\begin{array}{l}\text { Fewer women than men considered practice } \\
\text { lifestyle in choosing their career. Both men } \\
\text { and women considered lifestyle, elective in } \\
\text { the field of choice and faculty important in } \\
\text { career choice. }\end{array}$ \\
\hline Azizzabeh & 2003 & $\begin{array}{l}\text { 4th year } \\
\text { medical } \\
\text { students }\end{array}$ & $\begin{array}{l}111(48 \mathrm{M} / 31 \mathrm{~F} / 32 \\
\text { unknown) }\end{array}$ & Survey & $\begin{array}{l}\text { To determine factors that } \\
\text { influence career choice among } \\
\text { medical students }\end{array}$ & $\begin{array}{l}\text { Prestige and career opportunities are more } \\
\text { important to students seeking surgical } \\
\text { residencies. Concerns about lifestyle and } \\
\text { work hours are deterrents to surgery as a } \\
\text { career. } 19(17 \%) \text { students interested in } \\
\text { surgery. }\end{array}$ \\
\hline Figueireido & 1997 & $\begin{array}{l}\text { Medical } \\
\text { graduates }\end{array}$ & 821 & $\begin{array}{l}\text { Data } \\
\text { from } \\
\text { Medical } \\
\text { Faculty }\end{array}$ & $\begin{array}{l}\text { To examine the influence of } \\
\text { gender on the specialty choices } \\
\text { of graduates from a Brazilian } \\
\text { medical school during } 2 \\
\text { periods }\end{array}$ & $\begin{array}{l}\text { More male than female choosing surgery } \\
\text { during both study periods ( } 16 \text { vs } 2 \% \text { resp } 15 \\
\text { vs } 6 \% \text { ). }\end{array}$ \\
\hline Al-Faris & 1997 & $\begin{array}{l}5 \text { th (final) } \\
\text { year medical } \\
\text { students }\end{array}$ & $253(149 / 104)$ & $\begin{array}{l}\text { Cross- } \\
\text { sectional } \\
\text { study }\end{array}$ & $\begin{array}{l}\text { To identify the career choices } \\
\text { and reasons for career choices } \\
\text { of final-year Saudi medical } \\
\text { students }\end{array}$ & $\begin{array}{l}16 \% \text { students choose surgery. More men } \\
\text { chose surgery, more women chose obstet- } \\
\text { rics-gynecology and ophthalmology. }\end{array}$ \\
\hline Zulkifli & 1997 & $\begin{array}{l}5 \text { th (final) } \\
\text { year medical } \\
\text { students }\end{array}$ & $241(107 / 134)$ & $\begin{array}{l}\text { Cross- } \\
\text { sectional } \\
\text { study }\end{array}$ & $\begin{array}{l}\text { To investigate career choices } \\
\text { among Malaysian medical } \\
\text { students }\end{array}$ & $\begin{array}{l}\text { Surgery ranked highest among male } \\
\text { students, obstetrics and gynecology among } \\
\text { female students. }\end{array}$ \\
\hline Razali & 1996 & $\begin{array}{l}\text { 3rd year } \\
\text { medical } \\
\text { students }\end{array}$ & $?$ & Survey & $\begin{array}{l}\text { To investigate the reasons for } \\
\text { entry to medicine and the } \\
\text { career perspectives of phase III } \\
\text { medical students of a Malaysi- } \\
\text { an university }\end{array}$ & $\begin{array}{l}\text { No significant differences in the intention of } \\
\text { pursuing a career between genders, but } \\
\text { women were less likely to seek entrance into } \\
\text { private practice or pursue formal postgradu- } \\
\text { ate education. The choice of surgery as a } \\
\text { career was confined to men. }\end{array}$ \\
\hline Baxter & 1996 & $\begin{array}{l}\text { 4th year } \\
\text { medical } \\
\text { students }\end{array}$ & 245 & Survey & $\begin{array}{l}\text { To examine factors affecting } \\
\text { career choice by medical } \\
\text { students }\end{array}$ & $\begin{array}{l}\text { Male more likely to choose a surgical career } \\
\text { than females ( } 27 \% \text { versus } 10 \%) \text {. Males were } \\
\text { more likely to identity technical challenge, } \\
\text { earning potential, and prestige whereas } \\
\text { females were more likely to identify } \\
\text { residency conditions, part-time work, and } \\
\text { parental leave availability as important } \\
\text { qualities in a specialty. Females were less } \\
\text { likely to take surgical electives and more } \\
\text { likely to identify a lack of role models. }\end{array}$ \\
\hline
\end{tabular}


Table 5. Personality differences in undergraduate students interested in surgery

\begin{tabular}{|c|c|c|c|c|c|c|}
\hline Author & Year & Participants & $\begin{array}{l}\text { Number of } \\
\text { participants } \\
\text { male/female }\end{array}$ & $\begin{array}{l}\text { Type of } \\
\text { study }\end{array}$ & Study objective & Findings \\
\hline Mehmood & 2013 & $\begin{array}{l}\text { Medical } \\
\text { students }\end{array}$ & $546(336 / 218)$ & Survey & $\begin{array}{l}\text { To study the influence of } \\
\text { gender and the personali- } \\
\text { ty profiles of medical } \\
\text { students in their specialist } \\
\text { choices }\end{array}$ & $\begin{array}{l}\text { Surgery was the single most popular specialty amongst } \\
\text { both male and female students. Males had significantly } \\
\text { higher scores on the 'impulsive sensation seeking' scale } \\
\text { and students preferring a surgery specialty had the highest } \\
\text { score on the 'impulsive sensation seeking', 'neuroticism- } \\
\text { anxiety', 'aggression-hostility' and 'sociability' scales. }\end{array}$ \\
\hline Coulston & 2012 & $\begin{array}{l}\text { 2nd year } \\
\text { medical } \\
\text { students }\end{array}$ & $573(267 / 304)$ & Survey & $\begin{array}{l}\text { To study personality of } \\
\text { female medical students } \\
\text { attracted to the surgical } \\
\text { profession. }\end{array}$ & $\begin{array}{l}\text { Significantly fewer females rated surgery highly likely as a } \\
\text { career. Females interested in surgery had higher Neuroti- } \\
\text { cism and Agreeableness scores, and placed greater } \\
\text { importance on ability to help people, and less importance } \\
\text { on prestige and financial reward. Compared to males not } \\
\text { interested in surgery, females interested in surgery had } \\
\text { higher Openness scores, and placed greater importance on } \\
\text { ability to help people, interesting and challenging work, } \\
\text { and less importance on lifestyle. Females interested in } \\
\text { surgery had lower Agreeableness scores, and placed } \\
\text { greater importance on prestige and less importance on } \\
\text { lifestyle compared to females not interested in surgery. }\end{array}$ \\
\hline Hojat & 2008 & $\begin{array}{l}\text { Medical } \\
\text { students }\end{array}$ & $1076(517 / 559)$ & Survey & $\begin{array}{l}\text { To investigate the } \\
\text { relationship between } \\
\text { personality and specialty } \\
\text { interest }\end{array}$ & $\begin{array}{l}\text { Students interested in 'surgical' specialties obtain higher } \\
\text { scores on a measure of 'impulsive sensation seeking' and } \\
\text { lower scores on a measure of 'neuroticism-anxiety'. } \\
\text { Students interested in 'hospital-based' specialties score } \\
\text { lower on a measure of 'sociability' whereas those interest- } \\
\text { ed in 'primary care' score higher on this measure. Results } \\
\text { also showed that men scored higher on 'impulsive } \\
\text { sensation seeking,' and women outscored men in the } \\
\text { 'neuroticism-anxiety' and 'activity' scales. More male } \\
\text { interested in surgery. }\end{array}$ \\
\hline Austin & 2007 & $\begin{array}{l}\text { Medical } \\
\text { students 2nd, } \\
\text { 3rd and 5th } \\
\text { year }\end{array}$ & $273(85 / 188)$ & Survey & $\begin{array}{l}\text { To examine gender } \\
\text { differences in empathy } \\
\text { levels in medical students } \\
\text { at different levels of } \\
\text { education, and to } \\
\text { investigate whether } \\
\text { emotional intelligence } \\
\text { and empathy are related } \\
\text { to academic success }\end{array}$ & $\begin{array}{l}\text { Significant gender differences were found for the whole } \\
\text { sample on emotional intelligence, empathy and the } \\
\text { Utilization of Emotion subscale, with females scoring } \\
\text { higher than males on all } 3 \text { scales. There were no signifi- } \\
\text { cant gender differences in end-of-year marks in any of the } \\
3 \text { year groups, with male empathy scores increasing } \\
\text { between years } 1 \text { and 2, whilst female scores declined. }\end{array}$ \\
\hline Frantsve & 2002 & $\begin{array}{l}\text { Applicants to } \\
\text { a OMS } \\
\text { residency } \\
\text { program }\end{array}$ & $48(38 / 9)$ & Interview & $\begin{array}{l}\text { To examine effects of } \\
\text { applicants' personality } \\
\text { and gender on faculty } \\
\text { rankings and matching to } \\
\text { an Oral and Maxillofacial } \\
\text { Surgery residency } \\
\text { program }\end{array}$ & $\begin{array}{l}\text { Male applicants enjoy more teamwork and assume a } \\
\text { submissive role when interacting with authority figures, } \\
\text { female applicants less likely than males to be as friendly } \\
\text { and deferent in their interactions with male authority } \\
\text { figures. }\end{array}$ \\
\hline Batenburg & 1999 & $\begin{array}{l}\text { Final year } \\
\text { medical } \\
\text { students }\end{array}$ & $40(16 / 24)$ & Survey & $\begin{array}{l}\text { To asses patient- } \\
\text { centeredness of trainees } \\
\text { in general practice and } \\
\text { surgery and of final-year } \\
\text { clerks preferring one of } \\
\text { these specialties }\end{array}$ & $\begin{array}{l}\text { Professional attitudes, in particular patient-centeredness, } \\
\text { seem to be related to specialty preference in the final year } \\
\text { of graduate medical training and specialty as a career } \\
\text { choice: general practice trainees showed more patient- } \\
\text { centeredness than surgery trainees. Gender was not } \\
\text { related to patient-centeredness. }\end{array}$ \\
\hline
\end{tabular}

\section{Discussion}

Despite the dramatically increased entry of women into surgery, a traditionally male-dominated field, there remains a gross underrepresentation of women in leadership positions of these departments. ${ }^{10}$ Female surgeons perceive gender as a limitation to pursuing a career in academic surgery, ${ }^{6,9-11}$ this is not only a perception, since women are underrepresented in the major surgical societies, organizations and leading positions of academic departments of surgery. ${ }^{12-14}$ However, female surgeons seem to be more actively involved in teaching undergraduates, ${ }^{11,15,16}$ but there 
is an overall lack in the literature of recent studies that investigate this observation.

As Zhuge and colleagues pointed out, the major constraints of contributing to the glass-ceiling phenomenon are traditional gender roles, manifestations of sexism in the medical environment, and lack of effective mentors. ${ }^{9}$ Gender roles contribute to unconscious assumptions that negatively influence decision-making when it comes to promotions. The lack of role models in surgery in general, and academic surgery in particular, has been discussed in different articles as a possible explanation for the underrepresentation of women in surgical academia., ${ }^{9,54}$ Mentoring women to success in academic surgery, and identifying barriers to women entering surgery and achieving positions in academic surgery are prerequisites for correcting the existing gender inequities.

Sexism has many forms, from subtle to explicit forms, and some studies show that more women report being discriminated than men. Gender discrimination and bias has been reported as a consistently and significant career deterrent reported by female medical students. ${ }^{56}$

Female students pursuing a surgical career have experienced discrimination, ${ }^{37,38,57,53}$ although this is not an isolated phenomenon for the specialty: female students interested in a career in orthopedic trauma, or male students interested in obstetrics had such experiences. ${ }^{37,38,58,59}$

It is not clear if gender itself is a factor that affects the learning of fundamental surgical skills. ${ }^{24-35}$ Work experience, interest in surgery, training and previous video game experience seem to enhance the surgical skills of medical students. ${ }^{19,24,26,28,30}$ Greater exposure to surgery and previous experience in video games among male students could be some of the explanations for the better performance observed in various studies measuring laparoscopic skills, even though training seems to level out those initially observed differences. The overall decreased interest among female students in surgery, ${ }^{22,25}$ could be a possible explanation for women's poorer early performance. ${ }^{30}$

But it seems clear that gender is a determining factor for choosing surgery, with a consistently lower proportion of women compared to men interested in pursuing a surgical career $\left(15-42 \%\right.$ males vs. $2-29 \%$ females). ${ }^{42,46,49,54-64}$ The choice by females of surgery as a career is strongly associated with a higher proportion of women on the surgical faculty, ${ }^{41}$ again highlighting the importance of role models and mentoring. ${ }^{10,60-62}$

\section{Limitations}

The majority of the authors of the reviewed articles are women, and this can be a potential source of bias. Most of the articles that investigate students' attitudes, perceptions, personality and interest for surgery are surveys, where the students are self-selected for each study, itself representing a limitation of the study and thus being a source of potential bias. The intervention studies were done with the purpose 122 of setting up baseline laparoscopic skills or to demonstrate the hypothesis that training laparoscopic surgery in a simulation environment improves performance. As the majority of the studies come from North America, the results may not apply to other countries. There are, however, some studies from other countries with consistent overall results.

\section{Implications}

Gender equality, defined as the absence of discrimination on the basis of a person's gender in opportunities, is not a spontaneous process. However, gender differences must first be identified and the imbalance between the genders should be addressed and rectified. There are known differences between male and female physicians, and gender also plays a role when it comes to choosing a specialty. ${ }^{63,64}$ To highlight these differences and the apparent gender inequalities is the first step of working towards gender equality within surgical education.

Choice of surgery as a career by women is strongly associated with a higher proportion of women in the surgical faculty. ${ }^{41}$ The negative loop of few female role models in academic surgery that results in few female students interested in surgery will hardly change the trend of gender inequalities in surgery.

Many have postulated that women are deterred from a surgical career because it continues to have an aura of being an "old boys' club", and unfortunately, this review supports that statement. Bias against women in the field of surgery exists, and is a reality in the $21^{\text {st }}$ century.

\section{Acknowledgements}

The authors want to thank Ida Engqvist for linguistic support.

\section{Conflict of Interest}

The authors declare that they have no conflict of interest.

\section{References}

1. Bickel J. Gender equity in undergraduate medical education: A status report. Journal of Women's Health and Gender-Based Medicine. 2001;10(3):261-270.

2. Soreide K, Glomsaker T, Soreide JA. Surgery in Norway: beyond the scalpel in the 21st century. Archives of surgery (Chicago, Ill: 1960). 2008;143 (10):1011-1016.

3. Prichard D, Collins N, Boohan M, Wall C. Junior doctors and undergraduate teaching: the influence of gender on the provision of medical education. Teach Learn Med. 2011;23(2):155-160.

4. Quinlan R. Gender and the surgical workforce. Archives of Surgery. 2007;142(4):321-328.

5. Troppmann KM, Palis BE, Goodnight JE, Ho HS, Troppmann C. Women surgeons in the new millennium. Archives of surgery (Chicago, Ill: 1960). 2009;144(7):635-642.

6. Cochran A, Hauschild T, Elder WB, Neumayer LA, Brasel KJ, Crandall ML. Perceived gender-based barriers to careers in academic surgery. Am J Surg. 2013 Aug;206(2):263-8.

7. Deedar-Ali-Khawaja R, Khan S. Trends of surgical career selection among medical students and graduates: a global perspective. Journal of Surgical Education. 2010;67(4):237-248.

8. Cook DA, West CP. Conducting systematic reviews in medical education: a stepwise approach. Med Educ. 2012;46(10):943-52. 
9. Zhuge Y, Kaufman J, Simeone D, Chen H, Velazquez O. Is there still a glass ceiling for women in academic surgery? Annals of Surgery. 2011;253(4):637-643.

10. Flannery A. Success, women, and academic surgery. Surgery. 2002;131(6):670-1.

11. Tesch BJ, Wood HM, Helwig AL, Nattinger AB. Promotion of women physicians in academic medicine. Glass ceiling or sticky floor? the journal of the American Medical Association. 1995;273(13):1022-1025.

12. Sexton K, Hocking K, Wise E, Osgood M, Cheung-Flynn J, Komalavilas $\mathrm{P}$, et al. Women in academic surgery: the pipeline is busted. Journal of Surgical Education. 2012;69(1):84-90.

13. Jonasson $\mathrm{O}$. Leaders in American surgery: where are the women? Surgery. 2002;131(6):672-675

14. Morton M, Sonnad S. Women on professional society and journal editorial boards. Journal of the National Medical Association. 2007;99(7): 764-671.

15. Klingensmith $\mathrm{M}$, Anderson $\mathrm{K}$. Educational scholarship as a route to academic promotion: a depiction of surgical education scholars. American Journal of Surgery. 2006;191(4):533-537.

16. Mendoza KA, Hauge LS, DaRosa D. The responsibilities and contributions of professional educators in surgery departments. Am J Surg. 2004;188(2):126-130

17. Prichard D, Collins N, Boohan M, Wall C. Junior doctors and undergraduate teaching: the influence of gender on the provision of medical education. Teaching and Learning in Medicine. 2011;23(2):155-160.

18. Lee K, Vaishnavi S, Lau S, Andriole D, Jeffe D. "Making the grade:" Noncognitive predictors of medical students' clinical clerkship grades. Journal of the National Medical Association. 2007;99(10):1138-1150.

19. Helenius I, Sinisaari I, Hirvensalo E, Remes V. Surgical procedure skills of graduating medical students: effects of sex, working, and research experience. The Journal of surgical research. 2002;102(2):178-184.

20. Healy D, Fleming F, Gilhooley D, Felle P, Wood A, Gorey T, et al. Electronic learning can facilitate student performance in undergraduate surgical education: a prospective observational study. BMC Medical Education. 2005;5.

21. Adamczyk C, Holzer M, Putz R, Fischer MR. Student learning preferences and the impact of a multimedia learning tool in the dissection course at the University of Munich. Annals of anatomy = Anatomischer Anzeiger: official organ of the Anatomische Gesellschaft. 2009;191(4):339-348.

22. Lee J, Kerbl D, McDougall E, Mucksavage P. Medical students pursuing surgical fields have no greater innate motor dexterity than those pursuing nonsurgical fields. Journal of Surgical Education. 2012;69(3):360-363.

23. Elneel FH, Carter F, Tang B, Cuschieri A. Extent of innate dexterity and ambidexterity across handedness and gender: implications for training in laparoscopic surgery. Surg Endosc. 2008;22(1):31-37.

24. White M, Welch K. Does gender predict performance of novices undergoing Fundamentals of Laparoscopic Surgery (FLS) training? American Journal of Surgery. 2012;203(3):397-400.

25. Thorson CM, Kelly JP, Forse RA, Turaga KK. Can we continue to ignore gender differences in performance on simulation trainers? Journal of laparoendoscopic \& advanced surgical techniques Part A. 2011;21(4):329333.

26. Shane MD, Pettitt BJ, Morgenthal CB, Smith CD. Should surgical novices trade their retractors for joysticks? Videogame experience decreases the time needed to acquire surgical skills. Surg Endosc. 2008;22(5):12941297.

27. Donnon T, DesCôteaux JG, Violato C. Impact of cognitive imaging and sex differences on the development of laparoscopic suturing skills. Canadian journal of surgery Journal canadien de chirurgie. 2005;48(5):387-393.

28. Enochsson L, Isaksson B, Tour R, Kjellin A, Hedman L, Wredmark T, et al. Visuospatial skills and computer game experience influence the performance of virtual endoscopy. Journal of gastrointestinal surgery: official journal of the Society for Surgery of the Alimentary Tract. 2004;8(7):876-82; discussion 82 .

29. Grantcharov TP, Bardram L, Funch-Jensen P, Rosenberg J. Impact of hand dominance, gender, and experience with computer games on performance in virtual reality laparoscopy. Surg Endosc. 2003;17(7):10821085 .
30. Kolozsvari NO, Andalib A, Kaneva P, Cao J, Vassiliou MC, Fried GM, et al. Sex is not everything: the role of gender in early performance of a fundamental laparoscopic skill. Surgical endoscopy. 2011;25(4):1037-1042. 31. Szczepanik A, Spieszny M, Klocek T, Szczepanik M, Goroszeniuk D, Kubisz A, et al. Motor coordination assessment in practicing surgeons and medical students. Acta Chirurgica Belgica. 2010;110(3):317-322.

32. Madan AK, Harper JL, Frantzides CT, Tichansky DS. Nonsurgical skills do not predict baseline scores in inanimate box or virtual-reality trainers. Surg Endosc. 2008;22(7):1686-1689.

33. Madan A, Frantzides C, Park W, Tebbit C, Kumari N, O'Leary P. Predicting baseline laparoscopic surgery skills. Surgical Endoscopy and Other Interventional Techniques. 2005;19(1):101-104.

34. Rosenthal R, Gantert WA, Scheidegger D, Oertli D. Can skills assessment on a virtual reality trainer predict a surgical trainee's talent in laparoscopic surgery? Surg Endosc. 2006;20(8):1286-1290.

35. Mehrabi A, Glückstein C, Benner A, Hashemi B, Herfarth C, Kallinowski F. A new way for surgical education--development and evaluation of a computer-based training module. Computers in biology and medicine. 2000;30(2):97-109.

36. Snelling J, Sahai A, Ellis H. Attitudes of medical and dental students to dissection. Clinical anatomy. 2003;16(2):165-172.

37. Field D, Lennox A. Gender in medicine: the views of first and fifth year medical students. Med Educ. 1996;30(4):246-252.

38. Stratton TD, McLaughlin MA, Witte FM, Fosson SE, Nora LM. Does students' exposure to gender discrimination and sexual harassment in medical school affect specialty choice and residency program selection? Academic medicine: journal of the Association of American Medical Colleges. 2005;80(4):400-408

39. Babaria P, Abedin S, Berg D, Nunez-Smith M. "I'm too used to it": A longitudinal qualitative study of third year female medical students' experiences of gendered encounters in medical education. Social Science \& Medicine. 2012;74(7):1013-1020.

40. Lempp H, Seale C. Medical students' perceptions in relation to ethnicity and gender: A qualitative study. BMC Medical Education. 2006;6.

41. Neumayer L, Kaiser S, Anderson K, Barney L, Curet M, Jacobs D, et al. Perceptions of women medical students and their influence on career choice. Am J Surg. 2002;183(2):146-150.

42. Bhat S, D'souza L, Fernandez J. Factors influencing the career choices of medical graduates. Journal of Clinical and Diagnostic Research. 2012;6(1): 61-64.

43. Huda N, Yousuf S. Career preference of final year medical students of Ziauddin Medical University. Education for health. 2006;19(3):345-353. 44. Nohr KB, Andersen BS, Greve J. Gender, qualifications and choice of specialty of younger physicians in Denmark 1998-2003. Ugeskrift for laeger. 2007;169(13):1223-1227.

45. Cochran A, Melby S, Neumayer LA. An Internet-based survey of factors influencing medical student selection of a general surgery career. Am J Surg. 2005;189(6):742-746.

46. Sobral DT. Influences on choice of surgery as a career: a study of consecutive cohorts in a medical school. Med Educ. 2006;40(6):522-529. 47. Azizzadeh A, McCollum C, Miller III C, Holliday K, Shilstone H, Lucci Jr. A. Factors influencing career choice among medical students interested in surgery. Current Surgery. 2003;60(2):210-213.

48. Mehmood S, Khan M, Walsh K, Borleffs J. Personality types and specialist choices in medical students. Medical Teacher. 2013;35(1):63-68.

49. Hojat M, Zuckerman M. Personality and specialty interest in medical students. Medical Teacher. 2008;30(4):400-406.

50. Coulston C, Vollmer-Conna U, Malhi G. Female medical students: Who might make the cut? Psychiatry Research. 2012;200(2-3):457-63.

51. Batenburg V, Smal J, Lodder A, De Melker R. Are professional attitudes related to gender and medical specialty? Medical Education. 1999;33(7):489492.

52. Austin E, Evans P, Magnus B, O'Hanlon K. A preliminary study of empathy, emotional intelligence and examination performance in $\mathrm{MBChB}$ students. Medical Education. 2007;41(7):684-689.

53. Frantsve L, Laskin D, Auerbach S. Personality and gender influences on faculty ratings and rankings of oral and maxillofacial surgery residency applicants. Journal of dental education. 2003;67(11):1252-1259. 
54. Hoover E. Mentoring women in academic surgery: Overcoming institutional barriers to success. Journal of the National Medical Association. 2006;98(9):1542-1545.

55. Risberg G, Hamberg K, Johansson E. Gender awareness among physicians - The effect of specialty and gender. A study of teachers at a Swedish medical school. BMC Medical Education. 2003;3:1-9.

56. Yu T, Jain A, Chakraborty M, Wilson N, Hill A. Factors influencing intentions of female medical students to pursue a surgical career. Journal of the American College of Surgeons. 2012;215(6):878-889.

57. Fitzgerald J, Tang S, Ravindra P, Maxwell-Armstrong C. Gender-related perceptions of careers in surgery among new medical graduates: results of a cross-sectional study. Am J Surg. 2013 Jul;206(1):112-92012:8.

58. Chang JC, Odrobina MR, McIntyre-Seltman K. The effect of student gender on the obstetrics and gynecology clerkship experience. J Womens Health (Larchmt). 2010;19(1):87-92.

59. Mooij SC, Antony P, Ruesseler M, Pfeifer R, Drescher W, Simon M, et al. Gender-specific evaluation of student's career planning during medical study in terms of orthopaedic trauma. Zeitschrift für Orthopädie und Unfallchirurgie. 2011;149(4):389-394.

60. Ek EW, Ek ET, Mackay SD. Undergraduate experience of surgical teaching and its influence and its influence on career choice. ANZ J Surg. 2005;75(8):713-718

61. Baxter N, Cohen R, McLeod R. The impact of gender on the choice of surgery as a career. American Journal of Surgery. 1996;172(4):373-376.

62. Sanfey HA, Saalwachter-Schulman AR, Nyhof-Young JM, Eidelson B, Mann BD. Influences on medical student career choice: gender or generation? Archives of surgery (Chicago, Ill:1960). 2006;141(11):1086-1094.

63. Mobilos S, Chan M, Brown JB. Women in medicine: the challenge of finding balance. Canadian family physician Medecin de famille canadien. 2008;54(9):1285-1286 e5.

64. Neittaanmaki L, Gross EB, Virjo I, Hyppola H, Kumpusalo E. Personal values of male and female doctors: gender aspects. Soc Sci Med. 1999;48(4):559-568. 